\title{
Research on the Loopholes and Countermeasures of Logistics Financial Business in China
}

\author{
LIU SHEN \\ Fuzhou University of International Studies and Trade \\ Fuzhou Fujian, China, 350202
}

\begin{abstract}
By studying on the domestic scholars' discussion and research on logistics finance, this paper introduces the main operation mode of logistics finance. From two aspects: legal policy, operation practice, based on our country's actual financial current situation of logistics, and from the legal system, industry standards, business operations and other aspects to compare their features and differences. On this basis, we summarize the loopholes in China's logistics finance business from the above three aspects. Taking advantage of case analysis, citing the case of Huai Mineral Flow Crisis, combined with the summary of vulnerabilities, it analyzes the main reasons leading to its crisis. Using system analysis method, from various angles of the whole logistics financial business participants to deal with various aspects of the solution is put forward, improve problem solving ability, provided a beneficial reference for the development of the logistics financial.
\end{abstract}

Keywords-Logistics finance; Pledge financing; Pledge supervision; Risk control.

\section{THE PRESENT SITUATION OF LOGISTICS FINANCE IN CHINA.}

Compared with developed countries, our country in the field of logistics financial development lags behind, but thanks to the rapid development of logistics industry in our country, and constantly improve the level of technology, draw lessons from abroad to carry out the logistics financial business experience and advanced management technology, our country's logistics financial shows a tendency of rapid development, and generally experienced two stages of development [1].

\section{A. Stage 1: 1999 to 2007}

In the first stage, because logistics finance is in the embryonic stage in China, the legal policy foundation is weak. Only in the "security law" promulgated in 1995 about personal property and rights pledge of warehouse receipt pledge provisions and some provisions of "contract law" promulgated 1999 can be used as a guarantee of logistics financial business relationship between power and responsibility. The government's policy support for the logistics financial business is also lacking.

Supported by the Training Program of Fujian Excellent Talents in University
In the operation practice, Chengtong Group's China Material Storage \& Transportation Co., Ltd. began to operate inventory pledge financing at the end of the 20th century, becoming the first innovation in the field of logistics finance in China. As of 2005, Zhongchu Nanjing Smart Logistics Technology limited company has cooperated with more than 10 financial institutions to formulate logistics financial pledge supervision for corporate clients [2]. In the same period, COSCO Group and Sinotrans Group are actively exploring the practice of logistics and finance, and gradually developing the business such as production supervision, warehousing and warehousing.

\section{B. Stage 2: since 2006}

Since 2006, China's logistics finance industry has entered a period of rapid development. In 2009, the state council incorporated the logistics industry into the top ten revitalization planning industries, and the government attached great importance to the development of logistics finance, and promoted the publication of a series of relevant legal policies. In 2007 , the implementation of the property law effectively improved the institutional environment of logistics finance. In 2009 , the policy recommendations on logistics financing for logistics financial development was proposed to discuss the establishment of logistics Banks in China. In 2012, the 12th five-year plan for financial industry development and reform incorporated logistics finance into the planning and guidance of financial development reform.

In the practice of business, Zhongchu Nanjing Smart Logistics Technology limited company and Sinotrans Group have taken the lead in the development. After more than ten years of development, the Bank that signed the cooperation agreement with Zhongchu Nanjing Smart Logistics Technology limited company has developed to more than 20, including CITI Bank, Min Sheng Bank, Ping An Bank, Standard Chartered Bank and BNP Paribas.

Tianjin port group in 2007 to set up specialized responsible for port logistics financial franchise company, the company since has been established with 77 logistics enterprises development of the logistics financial business relations, 8.3 billion cumulative for port customer financing, and pull them into tens of millions of tons of cargo throughput.

Under the supply chain financial impact on the whole logistics industry, now some private logistics companies have also begun to enter the field of logistics finance, for example, 
Shunfeng, a representative of private express companies, set up a logistics finance business unit in 2014, and gradually began to lay out financial services on the enterprise and consumer side, which has developed warehouse financing, factoring, order financing and credit loan service products.

In the face of the broad market of logistics finance, more and more financial institutions are actively participating in the logistics finance business and become the driving force of development. Before 2012, Shenzhen Development Bank merged into Ping An Bank, but it did not stop in the innovation of logistics financial businesss [3]. In 2014, Ping An Bank's Modern Logistics Finance Division was formally established as the first domestic commercial bank business department specializing in the logistics industry, it has truly achieved the unification of the logistics financial market and the examination of loans. Based on the use of Internet of Things technology, cooperation with perception technology, reentering the commodity financial logistics business after the steel trade crisis, and build a "safe trade logistics backbone network" .In other words, the joint logistics companies set up funds together, providing services for logistics finance companies.

\section{CHINA'S LOGISTICS FINANCIAL BUSINESS LOOPHOLE}

\section{A. Loopholes in laws and regulations}

At present, the logistics market in China, relevant laws and regulations are imperfect, the base of the chattel real rights for security system is very weak, no special laws and regulations, promulgated in view of the logistics financial only "property law", "security law", some clauses in the contract law to business involved in the relationship between power and responsibility and dispute resolution to provide legal basis, but the logistics financial and specification is not comprehensive, easy to cause legal disputes. In terms of the system, there is no uniform and efficient registration system of property rights, and lack of a unified system of property rights for the public [4]. And our laws clearly stipulate the prohibition of mixed operations, the third-party logistics enterprises in our country can't follow UPS acquired the internalization of the first international bank to financial institutions, thus blocked the road for the development of professional logistics bank.

\section{B. Loopholes in industry specification}

China is still in the primary stage of logistics finance, there are many loopholes in the Industry specifications. First, the main problem is Information sharing issues.

Firstly, lack of national unified public logistics information platform and private enterprise credit information platform. Credit information is not fully regulated, which is not conducive to the promotion of credit risk management of financial institutions [5]. Moreover, the lack of sharing of business information between financial institutions as the main financing body, and the lack of business transaction information platform in the industry, provides a loophole for the repeated pledge.

Secondly, the information is exchanged between the financing subject, lack of necessary business information sharing, resulting in information asymmetry, and even information distortion problem, such as financing companies to get loans from the whitewash their financial information or withhold any real information to achieve trust bank, and the regulatory role of the third party logistics enterprise is unable to transfer the accurate information to the bank, will affect the bank's judgment, leading to the failure of the entire business.

\section{C. business factors and business operation loopholes.}

\section{1) Risk Control Process loopholes}

Most logistics companies lack awareness of risk control and a complete risk control system. The risk control system is based on the traditional logistics business [6]. Early warning and control of risks are mainly based on experience. Without relevant high-quality staff, a scientific and scientific risk control system in the field of logistics finance is established.

Secondly, most of the logistics companies involved in logistics finance have incomplete organizational and management structures. They do not have independent logistics financial risk control departments, and their management responsibilities and supervisory responsibilities are not separated. This can easily lead to unfavorable influences such as lack of professionalism and low efficiency.

\section{2) Monitoring process loopholes}

The loopholes in the monitoring process are more manifested in the review of financial companies by financial institutions and the monitoring of pledges by logistics companies.

In the current logistics finance business in China, logistics companies often only supervise the supervision and acceptance of pledges, and financial institutions need to be responsible independently for the review of logistics companies and borrowing companies [7]. In the process of investigating and auditing the borrowing companies, the banks have created loopholes for borrowing companies that lack credibility due to the lack of targeted auditing mechanisms and poor information exchange with logistics companies and other financial institutions. Some companies have falsely reported the actual value of inventory in order to obtain more credit lines, and financial institutions have distorted the evaluation results because they believe in the words of one of their parties. Even some enterprises apply for financing not for the purpose of 
putting into actual production, but for concealing transaction information for speculative activities.

\section{3) Custody process loopholes}

In China's logistics finance business, most of the storage methods for pledged goods are public warehousing. The enterprises that apply for credit will transport the pledged goods to the designated logistics company for unified storage supervision. And this frequent outbound and outbound transportation will in turn generate a huge cost, giving the financing companies a lot of pressure.

Sometimes limited by geographical resources or saving transportation costs, logistics companies will choose to lease third-party warehouses for safekeeping [8]. Third-party warehouses do not belong to the company, and there is a high risk of collateral security in the storage. Most logistics companies do not have the standard and supervision criteria for selecting third-party supervised warehouses. Therefore, the supervision of pledges is not transparent and there are loopholes in storage.

\section{COUNTERMEASURES ON CHINA'S LOGISTICS FINANCIAL BUSINESS LOOPHOLES}

\section{A. Countermeasures on Laws and regulations loopholes}

At the macro level, we must first improve laws and regulations. The government should further regulate the logistics finance business within the existing legal framework such as the "Property Law" and the "Guarantee Law." If it is possible to establish relevant laws and regulations regarding the pledge guarantee business on the basis of the Real Right Law [9].

It is necessary to establish a professional regulatory body to conduct macro-control on the logistics financial market, standardize the terms of the contract, and put forward certain measures for dishonest punishment, and at the same time increase the enforcement of the law enforcement agencies to increase the cost of breach of trust.

\section{B. Countermeasures on Industry standard loopholes}

Promote the establishment of public information platforms and national unified SME credit system from the industry level. Promote the establishment of information sharing systems among financial institutions, and ensure that financial institutions that carry out logistics financial services maintain information and intervene in loopholes that cause repeated mortgage problems.

For those parties that specifically participate in the logistics finance business, an information interaction system of the Internet should be organized to integrate information on the credit company's credit information, commodity information, and operational conditions into the network, and information networking technology is used to monitor the status of pledged goods in real time and the transaction process.
For the current mixed logistics financial markets, macro management agencies must establish a strict market access system, not only to make detailed requirements on the scale, hardware supporting facilities, and information technology level of the third-party logistics companies themselves[10]. It is also necessary to review the experience and credit status that logistics companies have accumulated in past operations.

Promote the standardization and liquidity reform of logistics financial collateral documents, such as the implementation of a standard warehouse receipt system, standardizing the terms and format of warehouse receipts, using prescribed formats, and printing in a prescribed manner to ensure the authenticity, uniqueness and validity of warehouse receipts Sex to prevent damage caused by false warehouse receipts[11]. In addition, financial institutions, third-party logistics companies, and financing companies must establish a unified evaluation standard for the value of pledges through negotiations.

\section{Countermeasures on Business Operation Loopholes}

1) Countermeasures on Risk Control Process Loopholes

It is necessary to embark on the establishment of a credit risk rating system for financing companies and to provide data support for the system by collecting, collating, and analyzing data of private enterprises, especially unlisted companies with undisclosed operating information [12]. Continuously improve the establishment of credit files through multi-party information sharing. Each financing company is not independent and must exist in a certain supply chain. Therefore, financial institutions also need to collect data on the supply chain where financing companies are located.

2) Countermeasures on monitoring process loopholes

Financial institutions should strengthen the monitoring of the creditworthiness of financing companies. They must conduct in-depth investigations into financing companies and focus on the operating conditions of the financing companies and the upstream and downstream companies in their supply chains. The detailed status of current assets and the use of financing funds should be used according to their purposes. And further understand the market share of financing companies [13], operating profit growth and sales growth and other data related to the future development potential, as the basis for monitoring repayment guarantees. The information platform and data processing system are used to continuously update monitoring information on the credit rating, financial status, and operating capabilities of the financing enterprise so as to improve the efficiency of the development of the logistics finance business, which also helps track the repayment of financing companies and the supervision of logistics companies. 


\section{3) Countermeasures on Custody process loopholes}

For logistics companies that engage in business cooperation with financial institutions, they must strengthen the professionalization of their own warehouse facilities and safety equipment, and use appropriate custodial strategies and means according to the nature of the goods and the requirements for safekeeping [14]. Formulate internal operational rules for warehouses, strengthen the safety awareness of managers, and regularly organize personnel to check pledges to ensure that they are in the best condition.

For outsourced third-party warehouses and financing enterprise warehouses, since the logistics companies participating in the main business do not have management authority, the storage risks are high and reasonable and wellcontained storage strategies should be arranged [15]. It is necessary to strictly determine the qualifications of outsourced warehouses and to constrain their custodial behavior through the formulation of sound contractual terms to improve the transparency and security of cargo storage.

\section{CONCLUSION}

China's logistics finance is undergoing the second phase of rapid development. However, compared with the developed institutional industry environment and business operation level in developed countries, the scale and level of China's logistics finance are still relatively backward, and there are many problems that need to be resolved. Our country urgently needs to improve the relevant laws and regulations of logistics finance, solve the problems caused by information asymmetry, and the management department must establish a strict market access system. Financial institutions should speed up the establishment of a dynamic risk control system and a credit rating system that are in line with the characteristics of logistics financial services. The loopholes in the logistics finance business proposed in this paper have some reference significance for financial institutions and logistics companies participating in logistics finance. However, there are still some limitations that need further improvement and research.

\section{REFERENCES}

[1] Sidney Rutberg. Financing the Supply Chain by Piggy-backing on the Massive Distribution Clout of United Parcel Service [J]. The Secured lender,2002, (6): 40-46.

[2] David Biederman. Logistics Financiers. The Journal of Commerce, 2004(20):40 42

[3] A1len N Berger, Gregory FU dell, A More Complete Conceptual framework for SME Finance[R].World Bank Conference on Small and Medium Enterprises: Overcoming Growth Constraints,MCl3121, October,2004,14-15.

[4] Weisun. Business models and solution architectures for SMB financing in a supply chain ecosystem [J]. Management Science, 2004, (8): 130133.

[5] Fenmore E. Making purchase-order financing work for you[J]. The Secured Lender,2004,60(2):20-24

[6] Erik Hoffman, Oliver Belin. Supply Chain Finance Solutions. Springer Berlin Heidelberg, 2011,12(5):667-672

[7] Diercks L A. Identifying and managing troubled borrowers in assetbased-lending scenarios[J]. Commercial Lending Review, 2004, 19(3): $38-41$

[8] Allen N Berger,Gregory FU dell. A More Complete Conceptual Framework for SME Finance, Word Bank Conference on Small and Medium Enterprises: Overcoming Growth Constraints,2012, 14-15

[9] W Barnett. What's in a Name-A Brief Overview of Asset-based Lending. The Secured Lender, 2011,53(6):80-82

[10] Ren Wenchao. Material bank and its practice. Scientific decisionmaking, 1998, (2): 18-20

[11] Zou Xiaoyu, Tang Yuanqi. Analysis of Logistics Finance [J]. Zhejiang Finance, 2004, (5): 20-21

[12] Feng Gengzhong. Analysis of Innovation Mode of Logistics Finance Business [J]. Forecast, 2007, 26(1):49-54

[13] LI Yixue, XU Wei, FENG Gengzhong. Comparative analysis and case study of domestic and foreign logistics finance business [J]. Management Review, 2007, 19(10):55-62

[14] Li Yixue, Xu Wei, Wang Fei. Comparative analysis and case study of inventory pledge financing business between China and foreign countries [J]. Business Economics and Management, 2007, 189(7):35-40

[15] Li Yixue, Wu Lihua. Order financing business risk analysis and management under the innovation of logistics finance $[\mathrm{J}]$. Contemporary Finance, 2008, 2008 (12): 66-70. 